\title{
FINANCIAL SCHEMES AND THEIR APPLICATIONS IN CRITICAL INFRASTRUCTURE
}

\author{
Jozef KLUČKA ${ }^{1}$
}

Review article

Abstract: $\quad$ The paper deals with the issue of critical infrastructure, with emphasis on the economic
aspect. Funding is the important precondition of critical infrastructure operation. Currently
in the Slovak republic and the EU, financial schemes are proposed whose primary function
is to implement the funding to improve safety in the SR and EU. The first scheme (SR) is
based on the tasks set by law. The second scheme is based on the EU strategy - funding is
associated with improving the security of its member countries.
Critical infrastructure, security, crisis management, critical infrastructure funding,
economic impact.

\section{Introduction}

One of the government's functions is to protect the citizens. Globalization, increasing independence and complexity, new technologies and climate change create new challenges for the government and its approach to security policy. The approach identifies significant assets in terms of State functions and protection of citizens ' life in it. This approach underlines the concept of critical infrastructure (CI).

The concept of the critical infrastructure has its political, social and economic dimensions. The paper deals with the CI - emphasizing the economic aspect. The economy of CI is important for several reasons: the first are the costs associated with the elements of CI and its business continuity; another reason is to identify elements of CI for the given level of safety and the relation between security and CI. The approach of quantifying losses, from which can be derived approach streamlining decision-making process for cases to minimize the associated risks with its occurrence, is presented in the paper. At the end of the paper, the financial mechanism of sectoral CI in the Slovak republic is described - working proposal and other items associated with its application.

\section{Materials and methods}

External and internal challenges, threats caused that the concept of CI was designed and implemented, which contains "... physical resources, services, information technology facilities, networks and infrastructure assets, which, if disrupted or destroyed, would have a serious impact on critical societal functions, including the supply chain, safety, security, economic or social well-being of people or of the functioning of the Union or its Member States (On the identification and designation of European critical infrastructures and the assessment of the need to improve their protection, 2008; Interinstitutional document, 2011).

The Act Nr. 45/2011 on critical infrastructure was approved in the Slovak Republic. It provides a definition of critical infrastructure elements as follows: "Disruption or destruction of civil engineering building, service in the interest of public and information system in the sector, having potentially serious adverse consequences or the conduct of economic and social functions of the Country, and thereby the impact on the quality of life, protection of life, health, safety, property and environment according the sector criteria and cross-cutting criteria." (Act Nr.45, 2011: 434).

CI can be described by:

- its assets, services and products,

- facts whose consequences can cause fatal impact on the activities of the whole society (economic and socio-political system),

- set of elements that are interconnected.

The specific feature of any CI is interdependency. It is a bidirectional relationship between two infrastructures through which the state of each infrastructure influences or is correlated to the state of the other (Rinaldi et al., 2001).

Interdependency has relations to:

- reliability of CI elements,

- identification of connections within sectors and among subsectors,

University of Žilina, Faculty of Special Engineering, Department. of Crisis Management, Žilina, Slovak Republic, jozef.klucka@fsi.uniza.sk 
- evaluation of economic impacts due to sector, subsector or element dysfunction.

Any CI consists of sectors, subsectors and elements that fulfill predefined objectives. Functionality of the sector transport has influence to e.g. economic and social security. Based on the analogy - defined functions of sectors, sub sectors and elements have interrelations to the security of State and its citizens. And in the other words, each element must be financially supported to keep the stability, functionality and its function (Keeping the Country Running: Natural Hazards and infrastructure, 2011).

\section{Results}

The key drivers and trends of critical infrastructure in the Slovak Republic are:

- the infrastructure is owned and managed by public and private sectors and the average age of structures increases,

- the cooperation between private sectors and state organizations is the challenge for the future; only cooperation can fulfill the objectives and increase security,

- the improvement, investments and maintenance costs are rising,

- the government is financing critical infrastructures - it is seen as the state objectives but the financial sources tend to be more and more limited,

- the cyber sphere started to be the most critical part of the infrastructure

- functionality of critical infrastructure is also determined by climate change and technological innovations.

The concept of CI comes from the idea to achieve the level of security while not to threaten fundamental functions of the State or system of States (EU). Therefore it is important:

- to perform investment and maintenance in order to keep predefined reliability of CI elements,

- to elaborate such schemes of cooperation among state authorities, operators of CI to support rational, effective approach,

- to establish such an early warning systems that minimizes consequences due to effects - cascade, escalation and common cause,

- to evolve the concept of National critical infrastructure, what means to establish organizational bodies responsible and capable to deal with the CI framework. (Critical Infrastructure Resilience Strategy, 2010).
Catastrophic consequences can be quantified financially - in relations to a very specific situation can be expressed very differently. (Grossi and Kunreuther, 2005; Hochrainer, 2006; Kelíšek et al., 2010; Šenovský, 2011). The application of appropriate measures in the right time may seem to be rather theoretical but in practice allows us to approve the hypothesis:

- because of CI effects (cascade, escalation and common cause) the consequences will be steep (exponentially) and therefore the objective on the system resilience is warranted.

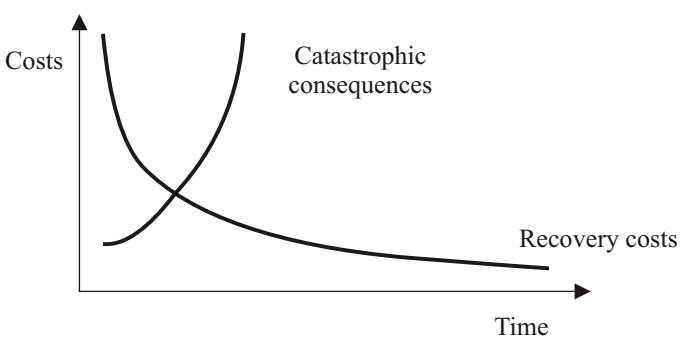

Fig. 1 Economic optimization conflict in crisis management

The intersection of curves expresses the conflict of crisis management optimization, where the cost of disaster recovery and the effects are these two variables. The intersection is a point where costs are economically viable for a given magnitude of the consequences.

After definition of elements based on the sectoral and cross-cutting criteria, it is important to propose a financial scheme. The traditional funding of CI comes from the state budget. Financial transfers from the budget are conducted to operators for their investments and operational activities based on the law.

According to the bill Nr.45/2011 about critical infrastructure:

„An operator has the claim to financial amount to fulfill obligations related with the application of measures (see $\S 10$ ) and to the central authority in the field of CI, an operator belongs to the sector and if the central authority declared it and this obligation comes from other regulations. Rules for providing financial contribution will be declared by the specific declaration issued by the responsible central authority. "

Based on the law the process of financial scheme in Slovakia is as follows:

- a central authority is appointed responsible for management (also financial) of relevant operator,

- operator submits the query to financial support to the competent central authority, 
- the central authority will review the eligibility of requirements (costs) accordance to law and internal regulations.

The financial requirements of the operator will have to be incorporated into the planning mechanism of the central authority. Also, because of possible extra costs it is suitable to think about the financial reserve for this type of situations.

The government of SR according to the law approves the strategy, interdepartmental program of CI to financially cover the objectives based on the law. It also defines sectoral criteria and it decides to incorporate/eliminate any element from CI. The government fulfils the objective of the central authority, whose functions are based on management and coordination of individual ministries, sectors and elements of CI. To accomplish this task it will be necessary to use the institutional and personal capacities in the Government Office.

The concept of control which is incorporated in the Ministry of Finance Working Paper (Interinstitutional document, 2011) has a specificity that has historical reasons. The control performs on the submitted paper documents is demanding not only financial control - adequacy in terms of the amount, but also eligibility requirements, which is related to the professional profile of control. In that regard, it seems to be consistent, if the transport sector is in the competence of the Ministry of Transport, Construction and Regional Development of SR. It is expected that staffing has the professional expertise and has the capacity to assess the requirements of the operator not only in terms of security but also the adequacy of CI to traffic safety. It is questionable whether this requirement is met if the Ministry of Finance - are subject to control are expenses applied in the information and communication technologies.

Law (Act Nr. 45, 2011) defines security measures to protect security of an element as follows ( $§ 10)$ :

- mechanical barriers,

- technical security resources,

- security elements of information systems,

- physical protection,

- organizational measures,

- control measures,

- and their combinations.

An operator declares its application to refinance expenses in relation to investment/operational expenses based on the law (1). After checking formal and content requirements, the implementation of payment or its denial is made (2) (and the operator is notified). To cover these requirements in the sector, a central authority has to formulate the request in the planning process for the Government of the SR (Ministry of Finance) to prepare assumptions for a draft of state budget (3). The government proposal is approved in the parliament (5) and the funds are allocated to the central authority (4). Based on the allocated funds, a central body (responsible for the sector) can finance the activities to support CI, required by the law.

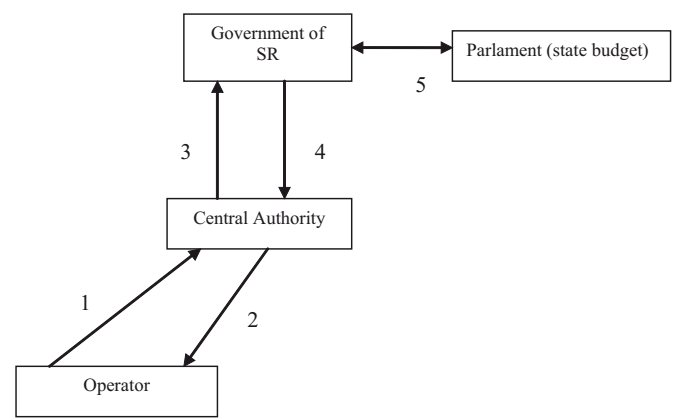

Fig. 2 Funding of CI in the SR

The financial amount for a sector and all sectors therefore creates significant requirements on resources from the state budget. The Government rational approach (identifying elements of CI vs. level of security measures) will be vital, which will not only solve the issue of financial resources availability but also a safety requirement dedicated to CI.

The European Union within the objective to increase security of Member States and across the Union is elaborating measures to increase their CI security. The Commission proposed to set up an Internal Security Fund (Interinstitutional document, 2011). The objective of the Fund will be to support strategic priorities that come from Union's Internal Security strategy:

- preventing and fighting against cross-border, serious and organized crime,

- raising the levels of security for citizens and business in cyberspace,

- preventing terrorism and addressing radicalization and recruitment,

- raising capabilities to protect critical infrastructure in all economic sectors,

- increasing Europe's resilience to crisis and disaster.

As can be seen from the list of objectives, the application of the Fund will be also directed towards $\mathrm{CI}$ funding. The EU not only declares the priority to secure CI but via the Fund it established financial sources to fulfill this objective.

Total amount of 1128 mil. $€$ is assumed for period of 2014-2020. This amount will be split 
in the ratio 50/50: member States will obtain an indicated amount of 564 mil.€ for national programs, emergency assistance and technical assistance. The rest will be implemented under direct and indirect management.

The current situation in Slovakia in this issue is as follows:

- Government Resolution Nr.356/2011 was approved, the document defines sectoral and cross-cutting criteria to determine the elements of CI (confidential)

- Government Resolution Nr.751/2011 was approved the document Proposal of a list of CI elements and their inclusion into CI sectors (confidential),

- individual ministries elaborate sectoral risk analysis.

\section{Conclusion}

For the near future it is important in the SR:

- define criteria to incorporate an element into CI ( take account relation between security and economy - available funding),
- analyze the experience of stakeholders and based on identified weaknesses apply the measures leading to greater efficiency and increased security of CI,

- create organizational structure, prepare the staff to deal with CI problems,

- elaborate strategy of National Critical Infrastructure,

- create permanent platform for communication of relevant subjects: ministries, operators and academics.

\section{Acknowledgments}

The paper was published within the research project APVV-0471-10 Critical Infrastructure Protection in Sector Transport.

\section{References}

Act No. 45/2011, on critical infrastructure (in Slovak).

Critical Infrastructure Resilience Strategy (2010) [online]. Australian government, 2010, ISBN: 978-1-921725-258 [cit. 2012-04-10]. Available at: www.ag.gov.au/cca.

GROSSI, Patricia, KUNREUTHER, Howard (2005). Catastrophe Modeling, Springer, Berlin, 2005, 245 s. ISBN 0-387-23082-3.

HOCHRAINER, Stefan (2006). Macroeconomic Risk Management Against Natural Disasters, Wien: DUV, 2006, 175 s. ISBN 978-3-8350-0594-5.

Interinstitutional document (2011). Council of EU, 2011/0368, Brussel, 2011 (working document).

Keeping the Country Running: Natural Hazards and infrastructure (2011) [online]. Cabinet Office, UK, 2011 [cit. 2012-04-10]. Available at: www.cabinetoffice.gov.uk/ukresilience.

KELÍŠEK, Alexander, KLUČKA, Jozef, ONDRUŠEK, Miloš, STRELCOVÁ, Stanislava (2010). Ekonomická bezpečnost' - výzva pre krízový manažment. In: Zborník z medzinárodnej-vedecko-odbornej konferencie Manažment teória, výučba a prax 2010, Liptovský Mikuláš, 2010, str. 146-152. ISBN 978-80-8040-404-8. (in Slovak).

On the identification and designation of European critical infrastructures and the assessment of the need to improve their protection (2008) [online]. COUNCIL DIRECTIVE 2008/114/EC of 8 December 2008 [cit. 2012-04-10]. Available at: http://eur lex.europa.eu/LexUriServ/LexUriServ.do?uri=OJ:L:2008:345:0075:0082:EN:PDF.

RINALDI, Steven M., PEERENBOOM, James P., KELLY, Terrence K. (2001): Identifying, Understanding and Analyzing Critical Infrastructure Interdependecies [online]. IEE Control Systems Magazine, USA, 2001 [cit. 2012-04-10]. Available at: http://www.ce.cmu.edu/ hsm/im2004/readings/CII-Rinaldi.pdf

ŠENOVSKÝ, Pavel (2011). Population Vulnerability Evaluation Against Long-Term Floods Impact [online]. In: Transactions of the VŠB - Technical University of Ostrava, Safety Engineering Series, 2011, Vol. .6, No. 1, pp. 34-39 [cit. 2012-04-10]. Available at: http://www.fbi.vsb.cz/export/sites-root/fbi/cs/sys/resource/pdf/veda-avyzkum/sbornik/2011-1-transactions.pdf. 